\title{
Educators' ICT Literacy: A Prerequisite for the Future of Education Post-COVID-19
}

\author{
Gerby C. Parra \\ Graduate School, University of Santo Tomas, Tagaytay Montessori School, Inc. \\ (Tagaytay, Philippine) \\ Email: gerbytms [AT] yahoo.com \\ ORCHID 0000-0003-2458-8737
}

\begin{abstract}
The education ecosystem was highly disrupted by the COVID-19 pandemic last March 2020, which forced school leaders and stakeholders to adopt an online learning platform to cope with learning continuity. However, educators encountered challenges in using technology to manage digital curriculum and technology-driven instruction due to the lack of Information and Communication Technology (ICT) skills and knowledge. This concept paper aims to highlight the need for educators' ICT literacy, which requires the support of new policies for educators to upgrade skills in managing the digital curriculum and effective online lessons delivery. Possessing ICT literacy skills will help educators be ready to transition to the new normal in education. ICT will be an integral component of the future of school education system after the pandemic.
\end{abstract}

Keywords - COVID-19 Pandemic, ICT Literacy

\section{INTRODUCTION}

The COVID-19 pandemic dramatically changed the way we teach and learn. It has radically reshaped the education landscape causing profound pressure on all countries' education systems. The pandemic's silver linings accelerated the transformation of the education ecosystem ushering in the 4th industrial revolution that uses technology in teaching and learning while forging connections among educators creating global solidarity [1] [2]. It is imperative to understand that today's decisions and choices will have enduring effects on the future of education [3] [4].

During the crisis onset, it threw all schools around the world into unchartered waters sending educators scrambling to mitigate the learning disruption of 1.5 billion affected learners globally with 130 country-wide closure of schools [5] [6]. However, Gouëdard et al. reported to the Organization for Economic Co-operation and Development (OECD) members that 188 countries closed schools, disrupting 1.6billion learners, and their families. Countries worldwide adopted various remote learning modalities such as radio and television education, modular instructional education, and online learning [3] [7]. That being said, the members of the OECD's 2018 Program for International Student Assessment (PISA) were not equipped for digital learning when the pandemic struck [8]. The OECD reported that its member school principals said that digital technology skills inadequacy hampers learning by 2\% in Singapore and 30\% in France [7]. While in the Philippines, 2.7million learners and 1million teachers and nonteaching staff were affected by the pandemic [9].

The schools who resisted technological change for decades, without hesitation, were forced to shift to online learning and adopted information and communication technologies (ICT) in such a short time [3] [7]. Throughout the pandemic, amidst the chaos and lack of technological knowledge and skills, educators relied heavily on e-learning tools to reformat to a digitalized curriculum and instruct lessons using technology to facilitate continuity of education [3]. Filipino teachers encountered the same challenges in creating technology-based curriculum and instruction design, despite the lack of technology skills [9].

Moreover, the pandemic has revealed vulnerabilities in the education system forcing everyone to appreciate the importance of technologies from social media, the internet, e-learning applications, artificial intelligence, virtual realities to other emergent technologies creating values in learning [10]. Since humans can adjust to the environment, those who adapt can thrive in the fourth industrial revolution, but those who can find opportunities to transition to Education 4.0 and become technologically literate to create innovative teaching content and engaging instructions will shape the future of education [2].

Doxtdator quoted the prominent philosopher John Dewey, "If we teach today's students as we taught yesterday's, we rob them of tomorrow" [11]. His words amplified the importance of advancing teaching and learning toward 21st-century 
education and Education 4.0 [2].

This paper's purpose is borne out of pressing urgency to address the research gap on the necessity for ICT literacy amongst educators as an imperative prerequisite to the future of education post-COVID-19. Somehow after the pandemic, education systems across the world will regain a sense of normality; but it will not be the same kind of education and schooling system applied before. School policymakers and stakeholders will play vital roles in embracing the new normal, possibly opting for a more sustainable, technologically adaptive, innovative, and equity-based education relevant to future needs [4]. Therefore, educators must possess ICT literacy and technical skills to facilitate online learning [8] [9] [12]. Educators should create engaging online content and effectively deliver online instructions [13].

This paper focuses on the Educators' ICT literacy relevance to the future of education post-COVID-19. The paper has three main objectives, first to amplify the relevance and benefits of Educators' ICT literacy for the future of education post-COVID-19. The second objective is to encourage policymakers to create or update policies committed to educators ICT literacy training to produce digitalized curriculum content and technologically based pedagogically appropriate instructions. And lastly, to have future ICT literate educators managing appropriate collaborative e-learning applications by being a tech-savvy content maker of digitalized curriculum and user of technologically-based pedagogical instruction.

\section{LITERARY REVIEW}

\subsection{ICT Literacy prior to COVID-19}

Before COVID-19, ICT has been extensively used in teaching since the ' 80 s and has enriched the learning process [14]. The continuous growth in the use of computers and access to the internet provided opportu nities for materials sharing, research, increased spending on hardware and connectivity; yet, little investment in educational software content and ICT teachers' training. However, schools that invested in educational technology have not fully embraced ICT's potential in the teachers' management of curriculum and instruction delivery [15].

The OECD report on the learning connections on students' ICT capabilities showed that online learning was not comparable to the value of doing face-to-face learning [16]. The report emphasized that technology application in education was sub-optimal and was not fully exploited since the presence of poor curriculum design, lack of ICT pedagogical skills, low-quality educational software, and naïve educational policy support to ICT were not yet realized [16].

On the contrary, countless research has pointed out that online education is as good as face-to-face learning. Its benefits include lower costs, time and space independent education, flexibility, improved virtual communication and collaboration, advanced critical thinking skills, and new technological skills [17]. These ideas were also pointed out by Obana, considering the Philippine educational system experience [9]. Online teaching provides an excellent way to overhaul the current teaching methods and models. Countries are looking for opportunities amidst this crisis to develop digital literacy, create education reforms, and improve teaching strategies [18].

\subsection{ICT Literacy Training}

The crisis revealed the unpreparedness of the education systems and the educators to online learning. Conversely, the COVID-19 experience magnified the teaching profession's value as educators weave through the technical difficulties and challenges in using educational technologies for online learning [7]. Throughout the pandemic, educators collaborated as they initiated, experimented, and innovated pedagogical strategies unleashing a resemblance of a meaningful transfer of learning [3] [4]. Montoya \& Barbosa mentioned that some teachers developed innovative makeshift ways to prepare digitalized curriculum and educational resources; however, it was a short-term band-aid solution [19].

Moreover, in a survey conducted across OECD countries last 2019, $18 \%$ of educators said that one of the most critical professional development they require is to develop ICT Skills [20]. Indeed, OECD confirmed that teachers identified ICT training as an urgent need in this current context [7]. It is also the second most requested training required by teachers after the Special Education training. Additionally, considering the current importance of online teaching and anticipation of future crises, ICT education, and usage even after COVID is a reality for educators and governments to invest in [3] [19]. Therefore, educational systems need to adopt effective professional development training for educators' ICT literacy [3] [16].

Furthermore, the core of schools' innovation and dynamism relies on professional development in this current rapid change. Educators have to upgrade their technology skills to be ICT literates [12] [15] [16]. In the Philippine education system, Obana stressed that teachers' ICT training is a significant consideration for schools to meet emerging needs [9]. According to Sukhomudrenko, modern education requires an advanced level of educators' professional training to include building competencies using ICT tools [21]. Simultaneously, the OECD affirmed the value of focusing on ICT 
usage's educational aspects, mainly on educators' training and professional development [15] [16]. Without a skilled and innovative use of ICT by educators, technology's potential will not be realized [3] [7] [15] [16]. The utilization of ICT can magnify great teaching pedagogies, but it cannot replace poor teaching strategies [16]. Therefore, it is suggested that incentives should be given to educators using ICT in developing new instructional approaches and creating a diverse curriculum [15]. Finally, technology can elevate the educators' role as co-creators of knowledge, as mentors, and as evaluators [7].

\subsection{ICT Literacy Application to Education}

As government eases out on the pandemic restrictions, schools will begin to transition to a very different educational model that requires a new educational policy or an upgrade of the existing system. This stage is vital, particularly in designing educational strategies and policies to ensure continuous effective learning [3].

Tria's study on the COVID-19 effects on the Philippine educational system stressed the importance of educational policies, particularly on the curriculum management and delivery of instruction, requiring strengthening to ensure that online teaching platform using technology can facilitate continued quality student learning [22].

While the report of UNESCO argued that schools cannot be replaced by distant or online learning; instead, a hybrid form of teaching and learning will substitute the traditional 18th century face-to-face classroom interaction [4]. In the Philippines, the direction for the hybrid or blended instruction caters to flexible spaces, be it in school or online at a flexible time, be it synchronous or asynchronous, and using an array of various educational tools and pedagogical methods [9]. The blending of face-to-face and online learning instructions will combine the best of both worlds to create innovative teaching and the best learning experience [7] [9]. Technology will be the driver of the future of education [23]. ICT has a pervasive effect on all sectors of the economy, including education, and reaping the benefits would entail structural reorganization and policy innovation [24].

Generally, ICT supports the effective use of technology, for it is the ability to develop skills and understanding to manage and operate ICT to find, evaluate, create, share, and communicate content [23] [24]. On the contrary, it is not anymore confined to computer skills, using technological devices, writing a text document, or sending emails. Instead, technology usage in education supports both the learning process through e-learning applications and are themselves the subject content to be learned [24].

Overall, ICT literacy encompasses skills in presentation tools, locating information, digital publishing, interpreting timelines, creating ownership and use, managing files, mapping and geospatial tools, online communication, and digital music or multimedia usage [25].

Moreover, below are examples of ICT in actions.

- Use of digital mapping tools for research tasks

- Use of presentation software to present findings that include text, graphics, and videos

- Use of video to analyze a topic to provide coaching or knowledge discussion

- Use of search engine for research

- Use of spreadsheet functions to create tables and records

- Use to sort

- Use to calculate and present data to identify trends

- Use for an online game that has a grid system to learn about direction

In addition, the Australian curriculum pointed out some ICT capability potentials applied to the content description for various learning areas, such as to use the software, including word processing programs, construct texts containing print, visual, and audio elements. Examples of this are Google slides or PowerPoint, accompanied by animations, videos, audio, images, and texts. Educators can learn how to present digitized lessons using these e-learning tools, cameras, microphones, and editing tools. They should often integrate technologies into lesson areas [25] and test them to determine which e-learning applications provide solutions for deeper understanding and student engagement [12].

\subsection{ICT Literacy on the Management of Curriculum and Instruction}

An expert in education and literacy from Mexico explained how to harness the potential of digital technology in teaching. Ms. Judy Kalma stressed the need to build robust educational systems that use digital skills in managing the different ways of teaching and learning. She highlighted educators' roles in applying digital skills in constructing knowledge [26]. Included in the report published by UNESCO, educators should tap digital technology as a source of innovation for knowledge construction, circulation, and accessibility. The management of curriculum content and instruction delivery aided by smart technologies, software, and hardware can produce adaptable, flexible, and personalized teaching and learning experience post-COVID-19 [6]. 
At the beginning of the COVID-19 pandemic, UNESCO appealed to every online knowledge provider to open educational resources to support online education and promote knowledge sharing [18]. These open-licensed resources can be redesigned, adapted, or used in assisting the teachers in their online teaching. Furthermore, Zhao et al. mentioned that many online libraries from the public, academic, and publishing houses worldwide offered free book resources to be downloaded.

Therefore, ICT capabilities can use ICT effectively to select which software, hardware, and e-learning tools to use for a specific task [13] [25]. Educators can choose, create, buy, or download from the abundant resources online. A significant component of ICT literacy is educators' ability to browse the web and use software or e-learning tools to manage curriculum and instruction. Bower \& Torrington created a list of free and easily accessible web-based learning technologies that educators can use to foster creativity in their curriculum and instruction management. Most of these applications are collaborative, interactive, and promote authentic learning offering innovative teaching solutions to create lesson contents and instructional strategies. The typology is composed of text-based, image-based, audio, video, multimodal production; digital storytelling, website creation, knowledge organization and sharing, 3D modeling, data analysis, learning management system, coding, assessment, social networking, and web-conferencing tools [27].

In addition to this, UNESCO also created a list of free online educational applications, e-learning tools, and resources to help educators ensure learning continuity [28].

\section{CONCLUSION AND FUTURE IMPLICATION FOR THE FUTURE STUDIES}

This paper highlights the concept on the relevance of educators' ICT Literacy for the future of education systems post-COVID-19. It encourages policy creation or upgrades, focusing on the management of technologydriven curriculum and delivery of instruction. It was discussed in this paper that across the world, the pandemic exposed the educational systems' unpreparedness to handle significant crises, and the best recourse is to seize the moment and learn from history. It is incumbent upon education policymakers and stakeholders to collaborate in identifying weaknesses and opportunities to plan for similar situations by strategically anticipating possible disruptions and the future needs of education. Inevitably, the use of technology to complement teachers management of curriculum and instruction and as a driver in students' engagement is an essential prerequisite to the future of education. Hence, this paper can serve as a reference for research studies on the importance of educators' ICT literacy related to the future of education after the pandemic.

Additionally, focusing on educators' technology training, technology application to education, types of engaging, collaborative e-learning applications for effective curriculum content making, benefits, and areas of concern should be heavily researched to facilitate technology potential in education. All this will help prepare for the future of education post-COVID-19.

It is known that great transformation and real change take place during crises. The education ecosystem was tremendously affected and transformed by the pandemic, and the possibility that the educational system's status quo will not resume to normal is foreseeable. Hence, the challenge is to analyze and evaluate what tran spired to strategically plan, prepare, and implement resilient and robust future-fit educational policies and strategies optimizing technology potential to help educational leaders deliver quality learning post-COVID-19.

\section{REFERENCES}

[1] Khagram, S., \& Davis, N. (2020, April 24). How the coronavirus pandemic accelerates the 4th Industrial Revolution. News wise. https://www.newswise.com/coronavirus/how-coronavirus-pandemic-accelerates-thetechnology-of-the-4th-industrial-revolution-https-eiuperspectives-economist-comfinancial-serviceswhycoronavirus-will-accelerate-fourth-industrial-revolution-4ir

[2] Miranda, G., \& Goodwin, J. (2020). Education 4.0. World Economic Forum. https://www.weforum.org/projects/learning-4-0

[3] Gouëdard, P., Pont, B., \& Viennet, R. (2020). Education responses to COVID-19: Implementing a way forward. OECD Education Working Papers, 224. OECD Publishing, Paris. https://doi.org/10.1787/8e95f977-en

[4] UNESCO. (2020e, June 22). Education in a post-COVID world: Nine ideas for publication. UNESCO. https://en.unesco.org/news/education-post-covid-world-nine-ideas-public-action

[5] UNESCO. (2020a, October 28). Are emerging technologies the way forward for Education? UNESCO. https://en.unesco.org/news/are-emerging-technologies-way-forward-education

[6] UNESCO. (2020c, September 8). Education: From disruption to recovery. UNESCO. https://en.unesco.org/covid19/educationresponse

[7] OECD. (2020b, June 30). The Impact of COVID-19 on Education. OECD. http://www.oecd.org/education/theimpact-of-covid-19-on-education-insights-education-at-a-glance-2020.pdf 
[8] OECD. (2020c, April 3). Learning remotely when schools close: How well are students and schools prepared? Insights from PISA. OECD. https://www.oecd.org/coronavirus/policy-responses/learning-remotely-when-schoolsclose-how-well-are-students-and-schools-prepared-insights-from-pisa-3bfdalf7/

[9] Obana, J. (2020, May 13). What will schools look like under the 'new normal'? Grant Thornton Philippines. https://www.grantthornton.com.ph/insights/articles-and-updates1/from-where-we-sit/what-will-schools-look-likeunder-the-new-normal/

[10] Netolicky, D. M. (2020). School leadership during a pandemic: navigating tensions. Journal of Professional Capital and Community, 5(3/4), 391-395. https://www.emerald.com/insight/content/doi/10.1108/JPCC-05-2020$\underline{0017 / f u l l / h t m l}$

[11] Doxtdator, B. (2017, February 12). Are we robbing students of tomorrow? Long View on Education. https://longviewoneducation.org/are-we-robbing-students-of-tomorrow/

[12] OECD. (2020d, March 23). Education Responses to COVID-19: Embracing Digital Learning and Online Collaboration. OECD Policy Responses to Coronavirus (COVID-19). http://www.oecd.org/coronavirus/policyresponses/education-responses-to-covid-19-embracing-digital-learning-and-online-collaboration-d75eb0e8/

[13] Li, C., \& Lalani, F. (2020, April 29). The COVID-19 pandemic has changed education forever. This is how. World Economic Forum. https://www.weforum.org/agenda/2020/04/coronavirus-education-global-covid19-onlinedigital-learning/

[14] Liaskos, J., \& Diomidus, M. (2002). Multimedia technologies in education. Studies in health technology and informatics, 65, 359-372. https://doi.org/10.3233/978-1-60750-909-7-359

[15] OECD. (2001). What Schools for the Future?. Schooling for Tomorrow. OECD Publishing. https://doi.org/10.1787/9789264195004-en

[16] OECD. (2015). Students, Computers and Learning: Making the Connection. PISA, OECD Publishing https://doi.org/10.1787/9789264239555-en

[17] Costley, P. (2019, November 5). What Is Industry 4.0 and Its Impacts on Education. MentalUP. https://www.mentalup.co/blog/industry-4-and-its-impact-on-education

[18] Zhao, J. H., Wu, P. Z., \& Liu, G. (2020, May). Guidance for Teachers: Online Education During COVID-19 Pandemic. UNESCO. https://iite.unesco.org/wp-content/uploads/2020/06/Guidance-for-Teachers.pdf

[19] Montoya, S., \& Barbosa, A. (2020, May 19). The Importance of Monitoring and Improving ICT Use in Education Post-Confinement. UNESCO UIS. http://uis.unesco.org/en/blog/importance-monitoring-and-improving-ict-useeducation-post-confinement

[20] OECD. (2019). TALIS 2018 Results (Volume I): Teachers and School Leaders as Lifelong Learners. TALIS, OECD Publishing. https://doi.org/10.1787/1d0bc92a-en

[21] Sukhomudrenko, Y. (2016). Implementation of Multimedia Technologies into the Educational Process in Developed Countries. Comparative Professional Pedagogy, 6(2), 96-101. https://doi.org/10.1515/rpp-2016-0025

[22] Tria, J. Z. (2020). The COVID-19 Pandemic through the Lens of Education in the Philippines: The New Normal. International Journal of Pedagogical Development and Lifelong Learning, 1(1). https://doi.org/10.30935/ijpdl1/8311

[23] OECD. (2020a, September 15). Back to the Future of Education: Four OECD Scenarios for Schooling. Educational Research and Innovation, OECD Publishing, Paris. https://doi.org/10.1787/178ef527-en

[24] Dostál, J., Wang, X., Steingartner, W., \& Nuangchalerm, P. (2017). Digital Intelligence - New Concept In Context Of Future Of School Education. ICERI2017 Proceedings, 3706-3712. https://doi.org/10.21125/iceri.2017.0997

[25] Vivian, R. (2014, October 17). What's The Difference Between ICT Capabilities \& the Digital Technologies Learning Area? Digital Technologies \& Education. https://digitaltecheducation.weebly.com/bits--bytesblog/whats-the-difference-between-ict-capabilities-digital-technologies-learning-area

[26] UNESCO. (2020b, September 15). Literacy teaching and learning in the COVID-19 crisis and beyond at heart of the International Literacy Day. UNESCO. https://en.unesco.org/news/literacy-teaching-and-learning-covid-19crisis-and-beyond-heart-international-literacy-day

[27] Bower, M., \& Torrington, J. (2020, April 29). Typology of Free Web-based Learning Technologies. https://library.educause.edu/resources/2020/4/typology-of-free-web-based-learning-technologies

[28] UNESCO. (2020d, July 7). Distance learning solutions. UNESCO. https://en.unesco.org/covid19/educationresponse/solutions 